ISSN:2528-9527

E-ISSN: 2528-9535

YIl Year. 11

Cilt Volume: 18

Sayı Issue :40

\title{
Kentte İnsan Hakları ve Kent Hakkı
}

\author{
DOI: 10.26466/opus.852445
}

\author{
* \\ Seçil Özdemir Metlioğlu* \\ *Dr. Öğr. Üyesi, İzmir Demokrasi Üniversitesi, Fen-Edebiyat Fakültesi, İzmir/Türkiye \\ E-Posta: secil.ozdemir@idu.edu.tr ORCID: 0000-0003-3165-0914
}

\section{Öz}

Sanayileşmenin ilk döneminden itibaren kente yerleşme ve kentte söz sahibi olma isteği yalnızca mekânsal bir hak isteği olmamıştır. Kent hem fiziksel hem de sosyokültürel bir olgu olması nedeniyle içinde bulunduğu toplum yapısı ile ilgili önemli bilgiler taşımaktadır. Kentsel mekânın hızlı bir biçimde dönüşümü, içinde bulunduğu toplum yapısını da hızla değiştirmekte ve toplum tarafindan değiştirilmektedir. Kent toprağının sakinlerine açılan alanlar, içinde bulunulan döneme ve iktidar yapısına göre değişmektedir. İktidar, kentin anlam dünyasını yaratmakta ve çerçevesini çizmektedir. Kente yerleşmede, kentte söz sahibi olmada ve kentteki hizmetlerin dağılımında sınıf mücadeleleri önemli bir rol oynamaktadır. Kentsel haklar, kent mekanmda yaşayanlarm, kente ait haklarmın neler olduğu ve kentsel mekan için alınan kararlarda söz sahibi olmaları üzerine tasarlanmıştır. Kentte insan haklarl; günümüzde kentlerde ortaya çıkan hak ihlallerinin engelleyebilmek adına dikkat edilmesi gereken hakları içermektedir. Kentle ilgili olan hakları tanımlamak, kentli hakları açısından önemli bir alanı tanımlayabilmeye olanağı sağlamaktadır. Bu makalenin amacı, kentte en temel insan hakkı olan "kent hakkı" kavramını tarihsel olarak açılamaktır. Makalenin diğer bir amacı mülkiyet hakkını, kent hakkı kavramı üzerinden tartışmaya açmaktır.

Anahtar Kelimeler: Kent, kent hakkı, kentli hakları, insan hakları. 
ISSN:2528-9527

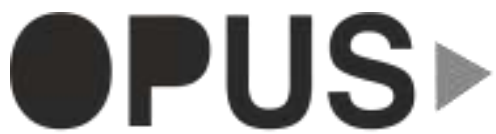

E-ISSN: 2528-9535

YIl Year: 11

Cilt Volume: 18

Sayı Issue :40

\title{
Human Rights and Right to the City
}

*

\begin{abstract}
Since the first period of industrialization, the desire to settle in the city and to have a say in the city has not only been a spatial request. Since the city is both a physical and a socio-cultural phenomenon, the city carries important information about the social structure it is in. The rapid transformation of urban space rapidly changes the structure of the society it is in and is being changed by the society. The areas open to the residents of the urban land vary according to the current period and the power structure. Power creates the city's world of meaning and draws its framework. Class struggles play an important role in settling in the city, having $a$ say in the city and the distribution of services in the city. Urban rights are designed on what the urban rights of the people living in the cities are and have a say in the decisions taken on the urban area. Human rights in the city; it includes rights that must be respected, fulfilled and protected in order to prevent violations of rights that occur in cities today. Defining the rights related to the city provides the opportunity to define an important area in terms of urban rights. In this article, the concept of the right to the city, which is the most fundamental human right in the city, is explained. Another purpose of the article is to discuss the property right over the concept of city right.
\end{abstract}

Keywords: City, right to the city, urban right, human rights. 


\section{Giriş}

Kentte insan hakları ve kent hakkı kavramları son yıllarda dünya çapında tartışılan ve bazı sözleşmelerle birlikte yasal zemine oturtulan kavramlardır.

Kentsel mekânla ilgili olan uygulamalarda kentsel haklar, önemli bir sorun alanı olarak ortaya çıkmaktadır (Özdemir-Sönmez, 2006). Kent ve kentli hakları, hâlihazırda uygulandığı biçimiyle son derece dar bir alanla kısıtlanmış, çoğu kez kenti kendi ihtiyaç ve arzuları doğrultusunda şekillendirme gücüne sahip bir sınıfın elinde bulunmaktadır (Harvey, 2013). Bu haklar, kentlilerin başta barınma hakkı olmak üzere, birçok hakkının ihlal edilmesine neden olmasını engellemektedir. İnsan hakları açısından değerlendirildiğinde, kentsel mekânda gerçekleştirilen her tür müdahalenin karmaşık dinamikleri etkilediği söylenebilir. Kentli hakları toplumsal süreçlerin şekillenmesinde önemli rol oynamaktadır (Şahin, 2015).

İzleyen bölümde kentli haklarının tartışmaya açılmasını sağlayan ve kentsel haklar açısından oldukça önemli bir kavram olan kent hakkı kavramı ayrıntılı olarak açıklanacaktır.

\section{Kent Hakkı}

Kent hakkı kavramı, 20 yy. da kentsel mekanda filizlenen sosyal ve politik yapılanmayı eleştiren bir değerler dizisini ifade etmektedir.

Harvey kent hakkını, var olana erişim hakkından daha öte, var olan mekânı değiştirme hakkı olarak nitelendirmektedir. Harvey'e göre bu değişim "Eğer deneyimle ve düşünerek hayatlarımızı aşırı stresli, yabancılaştırıcı, ya da sadece aşırı renksiz, rahatsızlık verici ve tatmin etmeyici bulursak, o zaman niteliksel olarak farklı bir tür kent inşa ederek bu gidişatı değiştirmeye ve kendimizi yeni bir imaj altında yeniden yaratmaya hakkımız vardır." Harvey'e göre, kentleşme, her zaman sinıfsal bir olgudur. Konut ise yalnızca barınak değil onun çok ötesinde bir şeydir. Artı ürün herhangi bir yer ya da kişiden sağlanırken artı ürünün denetimi birkaç elde toplanmaktadır. O'na göre kent hakkının ortaya koyduğu en önemli soru; "tam olarak kentleşme ve artı üretim ile kullanım arasındaki gerekli bağlantıya kimin hâkim olduğu" dur. Bu soruya cevap olarak "artı üretim ve 
kullanımı üzerinde daha büyük demokratik denetimin gerçekleşmesi gereklidir. Kentsel süreç artı ürün kullanımının önemli bir yolu olduğundan onun kentsel yayılması üstünde demokratik yönetim kurmak kent hakkın oluşturmaktadır" açıklamasını yapmıştır (2016, s.32).

Lefebvre (2014)'ya göre sosyal ilişkileri değiştirmek aynı zamanda mekânı değiştirmek anlamına gelmektedir. Harvey (2012), Engels (1992)'e referans ederek sözcüklerin ve kavramların döneme, zamana ve kişilere göre anlamlarının değişeceğinin altını çizmektedir. Mayer (2012), radikal kent talebi ile neoliberalizmin oyunlarına karşı dikkatli olunması gerektiğini söylemektedir. Bu üç hatırlatma sonrasında temel iddia, kent hakkı kavramını ve buna yönelik uygulamaları yeniden ve yeniden sosyal adalet ve kolektif bir bağlamda düşünmek ve bunda israr etmektir. Örneğin; yerel yönetim kanunlarına bakıldığında kimlerin karar merciinde yer aldığ1 ve kimlerin sadece görüş bildirebildiği konusunda dikkatli olmak gerekmektedir. Harvey (2013)'in artığın üretim ve kullanım sürecinde "herkesin" demokratik bir ortamda denetim ve yönetime katılma hakkının olduğunu belirtmesi bu noktada oldukça önemlidir.

Harvey, kent hakkını kontrol etme-demokratik katılım ve değiştirmeüretim hakkı olarak belirtmiştir. Lefebvre (1996), kent hakkını oeuvre hakkı ve temellük hakkı olarak tanımlamıştır. Oeuvre hakkını kentte yaşama sanatı olarak, temellük hakkını ise zaman ve mekâna el koymak olarak açıklamıştır. Mark Purcell ise bu iki hakkı şöyle açıklamaktadır.

"1) Katılım hakkı devletin, sermayenin ve mekân üretimini etkileyen herhangi başka bir kurumun kentsel mekânın üretimiyle ilgili karar alma süreçlerinde kent sakinlerine merkez rol tanuyan bir haktır. Kent sakinlerinin kentsel mekânda yaşama biçimlerini belirlemek için yaşanan mekânlarm oluşması süreçlerinde söz hakkı sahibi olmaları gerekmektedir. Onlara karar alma mekanizmalarmin merkezinde yer alma hakk verilmesiyle seslerinin sonucu etkileyebilecek kadar güçlenmesi kent hayatı üzerinde kurumsallaşmış bir kontrol mekanizmasının oluşmasını sağlamaktadır.

2)Temellük hakkın Lefebvre, kent mekânının kent sakinleri tarafindan gündelik yaşamlarında dolu ve bütün kullanımı olarak açıklamaktadır. Yani kentsel mekâna el koyma hakkı olarak temellük hakkı "kentsel mekânın içinde oynama, çalışma, onda temsil edilme, onu tanımlama, işgal etme" hakkım içerir. Marx'ın kullanım değeri ve değişim değerinde temellük hakkı kentsel mekânın kullanım 
değerinin değişim değerinin üstünde maksimum seviyeye çıkartılmalıdır" (Purcell, 2002, s.577-578).

Lefebvre, oeuvre kavramını eski kent mekânları olarak kullanmıştır. Değişim değeri yüksek bir kapitalist ürün olan kent mekânı yerine katılım ve temellük hakları oeuvre'ün gerçekleşmesini amaçlamaktadır. Oeuvre kentsel mekânın kullanımı ve üretiminde kent sakinlerinin aktif rol oynamasını ve kentin bütün imkânlarının kaderinin kentte yaşayan insanlar tarafından belirlenmesini amaçlamaktadır. Kent hakkı kentin kaderini kentte yaşayan insanlara bırakmayı, kentte sosyal adalet sağlamayı ve eşitliği yerine getirmeyi amaçlamaktadır. Kentte yaşayan insanlara kentte var olana erişim hakkı vermenin yanı sıra, onlara var olanı değiştirme hakkı sunmaktadır. Kent hakkı bütün bunlarla beraber insanların bütün farklılıklarıla kentte ikamet hakkı vermektedir. Kentleri hegemonya, hiyerarşi, parçalanma ve homojenleşmeden kurtarıp onları kolektif bir yaşam alanına yani oeuvre'ye dönüştürmeyi hedeflemektedir (Sadri, 2013).

Don Mitchell, Lefebvre'nın kent hakkını katılım ve temellük boyutlarını söyle açıklamaktadır:

1. Kent kamusaldır: sosyal etkileşim ve farklı insanların mübadele yapma yeridir. Kamusallık heterojenliği talep eder ve dolayısıyla kentin mekânı farklılıkla karşılaşmayı garantiye alarak, heterojenliğin temelini temin eder. Çeşitli insanların kent için farklı projeleri vardır ve bu farklı projelerin kenti şekillendirme konusunda uzlaşmasıyla insanlar vatandaşlık hakkına erişirler. Zira kent oeuvre olarak kolektif parçalardan oluşur ve böylelikle farklı insanların farklı yaşama ve ikame biçimlerine olanak sağlar.

2. Kent hakkı kentin mekânlarını kullanma hakkı, yani özetle kentte ikamet etme hakkı anlamına gelir. Bu hakkın sağlanması için bir öncelik olarak insanların konut hakkının yani, uyumak, dinlenmek, kimseden izin almadan tuvaletini yapabilmek için bir yere sahip olma hakkının sağlanması gerekmektedir. Böylelikle konut hakkı, kente el koyma ve temellükün bir şekline dönüşür ve bu da mülkiyet hakkından şu şekilde farklılaşır: mülkiyet hakkı dışlayıcıdır yani malike istenmeyen kişilerin erişimini kesme izni verir. Bu toplumun bazı kesimlerinin hiçbir mülke sahip olmadığı dünyamızda önemlidir. Kente el koyma hakkı 
olarak temellük hakkı ise dışlayıcı olmadan, toplumun her kesimi için kentte ikame etme hakkıdır. Bu nedenle konut hakkını mülkiyet hakkından ayrı tutarak, ikamet etme hakkı çerçevesinde ele almak gerekmektedir (Mitchell, 2003, s.18-23).

1960'larla birlikte kent, kentli hakları, kentsel haklar gibi kavramlar daha temel olarak tartışılan konular arasında yerini almıştır. Kente dair yapılan kavramsal tartışmalar yeni bir paradigmanın izlerini taşımaktadır. Yeni paradigmanın öne çıkardıkları; kentin bir üretim aracı olması, kentin kendisinin üretildiği ve kente dair söylenecek sözlerin katılımcı bir perspektiften kurgulanmasıdır. Kent, Marx'ın kapitalizm için söylediği sözlerden yola çıkarak üretilen bir mekân haline gelmiştir:

"Sermaye, bir yandan değişimi hızlandırmak için önündeki bütün mekânsal engelleri yerle bir etmek ve bütün dünyayı kendine pazar haline getirmek için, diğer yandan da mekânı zamanla aşmak için mücadele eder". (Kurtuluş, 2013).

Sermaye, değişimi ve kârı artırmak için sınırları anlamsızlaştırıp yerkürenin her alanını kendi pazarı haline dönüştürüyorsa, kent de aynı şekilde hem kapitalizmin bir üretim aracı haline dönüşmekte hem de sinırları zorlayarak artık kentler arası bir rekabeti öngören paradigmayı benimsemektedir. Dolayısı ile kent artık başlı başına araştırma nesnesi haline dönüşmektedir. Bu paradigma dönüşümünü Lefebvre'dan başlatmak gerekmektedir.

Lefebvre 1939 yılında yayınladığı "Diyalektik Materyalizm" adlı kitabında Marksist ekonomi politiğin, üretimin materyal yönünü ihmal ettiğini vurgulayarak, kapitalizmin üretim faaliyetlerinin bir mekânda sonuçlandığını ve materyalitenin bundan ibaret olduğunu açıklamaktadır (Zeybekoğlu Sadri, 2013, s.2). Lefebvre (1996) "kenti farklı bir şekilde nasıl düşünebiliriz?" sorusunun cevabını 1960'lardan itibaren vermeye çalışmıştır. 1968 yılında yazdığı "Writing on The City" adlı eserin gösterdiği en önemli şey; bugün adından çokça söz edilen "küreselleşme" olgusunun ipuçlarını vermesi ve mekânın üretilen bir şey olduğunu belirtmesidir. Lefebvre'nın çalışmalarında kent, Marksist bakış açısının izlerini taşımaktadır. Lefebvre'ya göre kapitalizm, varlığını sürdürebilmek için sürekli bir değişim halinde olmalıdır ve bu değişimi de mekânı sürekli kurgulayarak başarmak zorundadır. Gottdiener, kapitalizmin bunu nasıl başardığını Levebre'den aktarmaktadır: 
"Kapitalizm bir yüzyıldan bu yana kendi iç çelişkilerini (çözmese bile) yumuşatmayı becerebilmiş ve 'büyümenin' sağlanmasında başarılı olmuştur. Bunun, ne pahasına olduğunu kestirebilmekten uzağız, ancak araçlarmı biliyoruz: mekâna yerleşerek ve bir mekân üreterek" (Gottdiener, 2001, s.268).

Dolayısı ile yeni paradigmanın çıkış noktası burada yatmaktadır. Kapitalizmi anlamak için mekânı nasıl kullandığına ve nasıl ürettiğine bakmak gerekmektedir. Böylece kent artık başka türlü tahayyül edilen bir unsur haline dönüşmektedir. Yeni paradigmanın diğer bir katkısı da kentin yapısının ideolojik bir yapıdan oluştuğu düşüncesini tartışmaya açması ve kentsel ayrışma denilen durumun sınıfsal ayrışmaya göre şekillendiği vurgulamasıdır (Güler, 2011). Şengül (2001) ise kapitalizmin kendi sürekliliğini sağlamasının anahtarını, kapitalizmin bugün ulaştı̆̆ aşamada sermayenin, kent mekânını üretim, dolaşım ve tüketim ilişkilerinin örgütlendiği bir yer olmaktan ötede kurgulamasında aramaktadır. Dolayısı ile kapitalizmin gelişimi içinde kent mekânının kendisinin metalaştı̆̆ını ve sermaye birikim süreçleri açısından yaşamsal bir önem kazandığını ileri sürmektedir. Lefebvre, kapitalizmin bunu gördüğünü ve kendi krizini bu şekilde aştığını ifade ederek, kentin kendisinin üretim nesnesi haline dönüştüğünü ve kentin sınıfsal yapının bir parçası haline geldiğini belirtmektedir (Şengül, 2001). Kentsel gelişme süreçleri bu noktada kapitalist sistem içinde üretilen metalar şeklinde düşünülmekte ve buradan hareketle açıklanmaya çalışılmaktadır. Burada Lefevbre'nın öne çıkardığı kavram "sermayenin döngüsü" dür. Sermaye kendi krizini aşmak için yatırım aracı ya da bir bakıma kurtarıcısını ne olarak kodladığı sermaye döngüsü kavramının tanımını oluşturmaktadır. Sermayenin ilk döngüsü sanayi yatırımıdır. Kentler sanayi yatırımı üzerinden biçimlenmektedir. Ancak Lefebvre'nın üzerinde durduğu nokta "sermayenin ikinci döngüsü" dür. Sermaye sanayiyi değil de artık kenti bir meta olarak düşünüp doğrudan kente yatırım yaptığında ve etkinliğini gayrimenkul üzerinde gerçekleştirdiğinde sermayenin ikinci döngüsü oluşmaktadır (Kurtuluş, 2013). Kent artık bir yatırım aracı haline gelmekte ve kapitalizm krizini bu yolla aşmaya yönelmektedir. Lefebvre, kentlerin kuralsız büyümesini bu noktada açıklamaktadır. Kapitalizm tam anlamı ile krizini aşmak için kentlere saldırmaktadır. Sanayi ağırlıklı kapitalist üretimin kentsel ağırlıklı üretime dönüşmesini Lefebvre "kentsel devrim" olarak 
tanımlamaktadır (Şirin Pınarcıoğlu, Kanbak, ve Makbule, 2013). Kentler bu şekilde yeniden kurgulanırken Lefebvre'nın “TheProduction of Space" eserinde üzerinde durduğu nokta, toplumsal ilişkiler sadece bireyler arasındaki ilişkiye göre şekillenmez, kent de toplumsal ilişkilerin oluşmasında etken bir unsurdur.

Kent hakkı, ketsel hakların oluşması için önemli bir zemin hazırlamaktadır. Kent hakkı kavramı var olan kentsel düzenin ötesinde sistem karşıtı bir muhalefetin oluşmasında önemli bir rol oynamaktadır. Kent hakkı talebi, var olan kenti değiştirmek ve kentin üzerinde hak talep etme konusunda ortak bir isteğe dönüşmektedir.

\section{Tartışma ve Sonuç}

Toplumsal mücadelelerin görünür hale geldiği ve yeniden üretildiği bir sahne konumunda olan kentler, kentsel açık alanlar ve meydanlar tüm hak arama mücadelelerinin ve hak tanımlamalarının ayrılmaz bir unsuru haline gelmektedir.

Genel olarak kent hakkı kavramı, eşitsizliğin ekonomik anlamda sorunlara neden olduğunu ve kentleşmenin de bundan etkilendiğini, en büyük sorunun kentsel ayrışma sürecinde yaşandığını dile getirmektedir. Kentsel mekân üretiminin enformel arsa ve konut sektörünün sorunların çözümü noktasında teşvik edildiğini belirtmektedir. Enformel arsa ve konut piyasasının kentsel yoksulluğun daha da artmasına neden olduğunu ve genel anlamda kentleşmenin dengesiz bir biçimde gerçekleştiğini ifade etmektedir. Liberal yasal düzenlemelerin ve politikaların bu sorunların kökten çözümü noktasında eksik kaldığını ve önerilen politikaların ise bu sorunları daha da artırdığını vurgulamaktadır. Yasal politik reformların yeni vatandaşlık haklarının tanımlanması ile gerçekleşeceğine ve kentsel reformların bu yönde sürdürülmesi gerektiği üzerinden konsensüsün oluştuğunu dillendirmektedir. Bu noktadan sonra "kent hakkı" kavramının daha geniş bir biçimde tartışılmaya açıldığını ve bunun hukuksal düzenlemesinin nasıl olacağının düşünsel temellerinin planlandığını ifade etmektedir. Lefebvre, birey-toplum arasında yeni bir sosyal vatandaşlık kavramının oluşması gerektiğini vurgulamaktadır. $\mathrm{Bu}$ yeni vatandaşlık yaklaşımının ise Rousseau'nun toplum sözleşmesinin 
çok ötesinde ve daha kapsayıcı olduğunu belirterek, bu sözleşmenin politik mücadele sonucu oluştuğunu, dezavantajlı grupların korunmasını öncelediğini dile getirmektedir. Sosyal vatandaşlık kavramını yeni sosyal proje çerçevesi üzerinden alarak yeni bir anlaşmanın taraflarını da belirlemektedir. Bu yeni antlaşma ile kent, kapitalizmin eşitsiz gelişiminin yükünü taşımaktan öte kullanım değerinin öncelliği ile yeniden kurgulanmaktadır. Kentsel sorunları artıran liberal politikaların enformel arsa spekülasyonunu öngördügünü, mülkiyet hakkına yönelik "kolaylaştırııı" düzenlemelerin yapıldığı ve bireysel mülkiyetin ön plana çıkarıldığı ve sosyal barınma kavramının yok sayıldığı ifade edilmektedir. Bütün bu uygulamaların temsili demokrasi aldatmacası ile şekillendiği, kentler arasındaki eşitsizliğin bu nedenle arttı̆̆1 ve kentlerin bir rant aracı haline dönüştüğü dillendirilmektedir. Buradan hareketle kentlerin mülkiyet hakları ve devlet düzenlemeleri üzerinden düşünülmemesi gerektiğinin tartışıldığg, tartışma sonrasında kenti planlama hakkı, sosyal konut hakkı, çevrenin korunması hakkı, artık değerin ele geçirilmesi hakkı ve enformel yerleşmelerin düzenlenmesi hakkı gibi somut talepler üzerinden hareket planının oluşturulduğu ifade edilmektedir. Tüm bu taleplerin görünür olması için kentsel hukuk ve kentsel yönetim tarafından kabul edilip somut adımlar atılması gerektiği bu konuyu tartışan herkes tarafından onaylanmaktadır. Sürecin sonunda yerinden yönetimin önemli olduğu, yerel ile merkez arasındaki ilişkilerin güçlendirilmesi gerektiği vurgulanarak yeni yasal idari çerçevenin oluşturulması için devlet, toplum, gönüllü sektörlerin konumları netleştirilmesi gerektiği kabul edilmektedir. Burada diğer önemli bir nokta katılımcı demokrasi ve katılımcı bütçe planlamasıdır. Yerel yönetişim ve doğrudan demokrasi tüm bu süreci besleyen önemli unsurlardır. Bütün bu süreç, herkes tarafından kolay kabul gören bir durum yaratmamaktadır. Yeni yasal hükümler konusunda çok büyük tartışmalar çıkması ve özel çıkarlarının azaldığı noktalarda kimi kurum ve kişilerin bu tartışmalarda öne çıkan hakları geri çevirmesi kaçınılmaz hale gelmektedir. Örneğin, sosyal barınma hakkının özel mülkiyet çıarlarını zarara uğratması gibi durumlarda katılımcı bütçe planlaması ve katılımcı demokrasinin önemi giderek artmaktadır. 


\section{EXTENDED ABSTRACT}

\section{Human Rights and Right to the City \\ * \\ Seçil Özdemir Metlioğlu \\ Izmir Demokrasi University}

Since the city is both a physical and a socio-cultural phenomenon, it provides important information about the social structure it is in. The rapid transformation of urban space rapidly changes the structure of the society it is in and is changed by the society. Spaces opened to residents of the urban land vary according to the current period and the power structure of the period.

Power creates the city's world of meaning and draws its framework. Class struggles play an important role in settling in the city, having a say in the city and the distribution of services in the city. With the 1960s, concepts such as city, urban rights, and urban rights have taken their place among the more fundamentally discussed topics. Conceptual discussions about the city bear the traces of a new debate. The highlights of the new debate; the city is a means of production, the city itself is produced, and the words to be said about the city should be constructed from a participatory perspective. Urban rights are designed based on the rights of the people living in the cities and having a say in the decisions taken on the urban area.

The concept of right to the city symbolizes the resistance that emerged with the effect of the social and political structuring that started in the 20th century. Harvey (2016, p.32) defines the right to the city as the right to change the existing space rather than the right to access the existing. The right to the city means the right to use the city's spaces, that is, the right to reside in the city. In order to ensure this right, people's right to housing must first be secured (Mitchell, 2003, p.18-23).

According to Harvey (2016), urbanization has always been a class phenomenon. Housing, on the other hand, is not just a shelter but something far beyond that. The surplus product is obtained from any place or person, while the control of the product is collected in several hands. Harvey defines the right to the city as the right to control- 
democratic participation and change-production. Lefebvre (1996), defined the right to the city as the right to oeuvre and the right of appropriation. Lefebvre declared the right to Oeuvre as the art of living in the city, and the right to appropriation as the seizure of time and space. Lefebvre (1996), "How can we think of the city differently?" has tried to answer the question since the 1960s. The most important thing that the work "Writing on the City", written in 1968, shows is that it gives clues to the phenomenon of "globalization", which is mentioned much today, and that the space is something produced. To understand capitalism, it is necessary to look at how capitalism uses and produces space. Thus, the city is now transformed into an otherwise imagined element. Şengül (2001) seeks the key to capitalism's continuity in its construction, beyond being a place where the relations of production, circulation and consumption are organized; at the stage capitalism has reached today. Şengül therefore argues that in the development of capitalism, the urban space itself has become commoditized and has gained vital importance in terms of capital accumulation processes.

The concept of urban rights has made it a priority target to protect disadvantaged groups such as the poor, women, children and minorities, who are likely to be at risk in urban areas. According to Harvey (2013), all these people think that the struggle over the city as a whole can be easier after struggling for years alone with questions such as homelessness, gentrification of the city, and displacement. In the context of urban social movements, it is interesting, and at the same time very valuable, to describe the course of demands and movement through slogans.

With the inclusion of the concept of the right to the city in Brazil's constitution in 2001, the social struggle in those lands was turned in favor of the majority. Edésio Fernandes' article titled "Building the Right to the City in Brazil" expresses clearly how Lefebvre's "right to the city" concept is experienced in urban development in Brazil and what kind of difficulties are experienced. The Brazilian experience is important at this point; the "libertarian" side of the liberal discourse is that it does not actually follow a libertarian solution for the solution of social problems. Especially when the property right is opened to discussion over the concept of city right, it is seen that the property right envisaged by 
capitalism is accepted by the liberal discourse and therefore the other class and groups in the city should be positioned against this line. Achieving gains through the concept of city right in favor of the majority in this contrast is also a promising experience (Mayer vd., 2012). It is acknowledged by everyone who discusses this issue that for these demands to be visible, urban law and urban government must accept and take concrete steps. At the end of the process, it is acknowledged that decentralization is important and the relations between the local and the center should be strengthened, and the positions of the state, society and voluntary sectors should be clarified in order to establish a new legal administrative framework. Another important point here is participatory democracy and participatory budget planning. Local governance and direct democracy are important factors that feed this whole process. It becomes inevitable for some institutions and individuals to refuse the prominent rights in these debates when there are great debates about new legal provisions and when their private interests diminish.

\section{Kaynakça / References}

Engels, F. (1992). Konut sorunu. Ankara: Sol Yayınları.

Fernandes, E. (2007). Constructing the right to the city'in Brazil. Social $\mathcal{E}$ Legal Studies, 16(2), 201-219.

Gottdiener, M. (2001). Mekan kuramı üzerine tartışma: Kentsel praksise doğru. Praksis (Kent ve Kapitalizm), Ankara.

Güler, M. (2011). Kentsel haklar, kapitalizm ve katılım. Ankara Üniversitesi SBF Dergisi, 66(01), 49-71.

Harvey, D. (2012). Rebel cities: From the right to the city to the urban revolution. London: Verso Books.

Harvey, D. (2013). Asi şehirler. İstanbul: Metis Yayınları.

Harvey, D. (2016). Kent deneyimi. İstanbul: Sel Yayıncilı.

Kurtuluş, H. (2013). Kent sosyolojisinde değişen kavrayışlar ve Türkiye'nin kentleşme deneyimi. İçinde Türkiye Perspektifinden Kent Sosyolojisi Çalışmaları (s.177-227). İstanbul: Örgün Yayınevi.

Lefebvre, H. (1996). The right to the city. Writings on cities. UK: Blackwell Oxford.

Lefebvre, H. (2014). Mekânın üretimi. İstanbul: Sel Yayıncllı. 
Mayer, M. (2012). The "right to the city" in urban social movements. Cities for people, not for profit: Critical urban theory and the right to the city, 6385.

Mayer, M., Demirci, Ç., ve Çavuşoğlu, D. (2012). Kentsel toplumsal hareketlerde kent hakk1. Eğitim Bilim Toplum, 9(36), 153-182.

Mitchell, D. (2003). The right to the city: Social justice and the fight for public space. New York: Guilford Press.

Özdemir-Sönmez, N. (2006). Düzensiz konut alanlarında kentsel dönüșüm modelleri üzerine bir değerlendirme. Planlama, 36, 121-128.

Purcell, M. (2002). Excavating lefebvre: the right to the city and its urban politics of the inhabitant. GeoJournal, 58(2-3), 99-108.

Şahin, Ç. (2015). Türkiye'de kentsel dönüşüme dayali inşaat odakli ekonomi modeli ve toplumsal maliyeti: En temel insan haklari, sosyal haklar, çevre hakki ve kent hakki açisindan eleştirel bir değerlendirme. Sosyoloji Konferanslarl, 1(51), 51-81.

Şengül, H. T. (2001). Kentsel çelişki ve siyaset/kapitalist kentleşme süreçleri üzerine yazılar. İstanbul: Demokrasi Kitaplığı.

Şirin Pınarcıoğlu, N., Kanbak, A., ve Makbule, Ş. (2013). Kent kuramları. İçinde Ö. Uğurlu, P. Şirin Nihal, A. Kanbak, ve M. Şiriner Önver (Ed.), Türkiye Perspektifinden Kent Sosyolojisi Çalışmaları (s.71-103). İstanbul: Örgün Yayınevi.

Zeybekoğlu Sadri, S. (2013). Kentsel dönüşüm ve kentte insan hakları. İstanbul: İstanbul Bilgi Üniversitesi Yayınları.

\section{Kaynakça Bilgisi / Citation Information}

Özdemir Mertoğlu, S. (2021). Kentte insan hakları ve kent hakkı. OPUSUluslararası Toplum Araştırmalan Dergisi, 18(40), 2731-2743. DOI: 10.26466/opus.852445. 